EIS 11/2017

An Exploratory Analysis of Latvian Brands Competitiveness in China

Submitted 04/2017

Accepted for publication

08/2017

\section{An Exploratory Analysis of Latvian Brands Competitiveness in China}

\author{
Haidong Feng, Janis Priede
}

Faculty of Business, Management, and Economics, University of Latvia, Aspazijas blvd 5, Riga, Latvia E-mail: fenghd12@lzu.edu.cn

Гrossef http://dx.doi.org/10.5755/j01.eis.0.11.18913

In the past several years, China is entering a new stage of country 's economic development. Due to these changes of foreign brands also are switching their position towards Chinese consumers. The attitudes that consumers have towards international brands have been studied in the western countries for some time now. On $6^{\text {th }}$ November 2016, the 5th Summit of China and Central and Eastern European Countries (CEECs 16+1 Cooperation) was successfully held in Riga, Latvia. On the behalf of Guidelines which were made to help the cooperation between Central and Eastern Europe and China, some Latvian companies adopted an approach that emphasizes relation building with local agencies. However, these companies don 't do enough marketing planning and their activities in this field are implicit, because they do not understand Chinese consumers and their shopping habits. In order to enter Chinese market and expand the business here, entrepreneurs must understand the mindset and preferences of Chinese consumers. Through some marketing survey in Beijing, Shanghai, Guangzhou, Chengdu, Nanjing, Hangzhou, the author collected the marketing research data of consumer preference by questionnaires among the six largest cities in China. Through some marketing theories, SWOT analysis, data statistics, the research gets a comprehensive analysis result. By taking a fresh look at the marketing researches amidst latent consumer conception and behavior further, this study generates gaining experiences of Latvian brands building in China market. Then the conclusion will show the suggestions of how Latvian international brands adjust their marketing changes to raise their brands competitiveness in Chinese consumption patterns and to address the impact of consumer behaviors and marketing activities successfully.

KEYWORDS: Consumer, China, Marketing, Preference, Brand, Product.

European products purchasers are different from the buyers of Chinese consumer products. Chinese consumers have different motivation and other factors for buying European products, and different motivation for buying Chinese products. As the Boston Consulting Group (BCG) concluded in 2009, China will become the largest market for Latvian products in upcoming years. Latest data of post-economical financial crises of 2014-2016 shows that China's share in imported brands consumption rose to $31.4 \%$, Alon \& Chan (2009), and become the leading market since the beginning of the 2011, Li \& Kambele (2012). Together, China is becoming the destination for $36.8 \%$, Zhou \& Wang (2014), of world high end brands. Keeping in mind this information, it is extremely vital for Latvian goods producers to know and understand the consumers behaviors of Chinese specially the affluent Chinese, and new consumers of Latvian brands. For decades, branding and marketing research have been based on a concept of consumer behavior that is deeply embedded in a linear notion of marketing activities. This notion has been expressed in different forms, including steps in the selling process, Gertner (2011), adoption of innovation,

Zhang \& Leeflang (2014), the hierarchy of effects, Chu \& Sung (2011), and competitiveness mea-
European Integration Studies No. 11 / 2017

pp. $174-185$

DOI 10.5755/j01.eis.0.11.18913

(C) Kaunas University of Technology 
surement, Bulis \& Skapars (2012). Although this concept has been challenged from time to time, Kozlinskis \& Losane (2011), it has endured as a key organizing framework for brands building and marketing strategy. However, confronted by change, technological advancement, competition and the unpredictability of Chinese market, today's brands building has been compelled to seek a deeper understanding of the connection between brands and consumers, Dickson, Lennon, Montallo, Shen \& Zhang (2004). In turn, this had led to the search for new approaches and tools that will help Latvian marketing researchers understand the interaction among attitudes, emotions and brand choice, Mooij \& Hofstede (2011).

Rapid economic development, government policy and cultural factors have made Chinese affluent people different from consumers in the most developed markets in the Western countries as well as in the Eastern Asian countries (i.e Korea). Despite the increasing competitiveness of marketing Latvian brands in China, academic research on Chinese 5 affluent consumers buying process is rare or inexistent. In this paper, the authors will fill this gap and propose an effective business model for prospective as well as existing Latvian products exporting to China. This paper is developed theoretically and based on systematic literature review as well as content previous academic analysis and practical marketing survey. First of all, we will make a marketing survey of the distribution of Latvian brands consumers in different age groups. And investigate how their purchasing habits and consumption behaviors are different, and how their buying process of each product differs from their point of view. Secondly, the authors will explain our methodology followed by marketing positioning and discussing on the case study of successful marketing of Latvian brands in emerging China. Then analyze the channels for improving Latvian brands competitiveness, and the strategies of new Latvian brands marketing in China. At last, the conclusion remarks as well as suggestions of Latvian brands building will be given in the end of the paper. Figure 1 below illustrates a logical diagram of the analysis of Latvian Brands competitiveness in China.

Novelty of this paper: most researches just analyzed the theoretical marketing model about brands competitiveness, but in this paper the author uses the practical work and marketing survey to discover the actual Chinese consumer behavior and analyze different consumer group by different age range.

The subject in this paper is the effective marketing strategies of Latvia brands in China. Through the case study, marketing research and the exploratory analysis of marketing prospect, the pa-

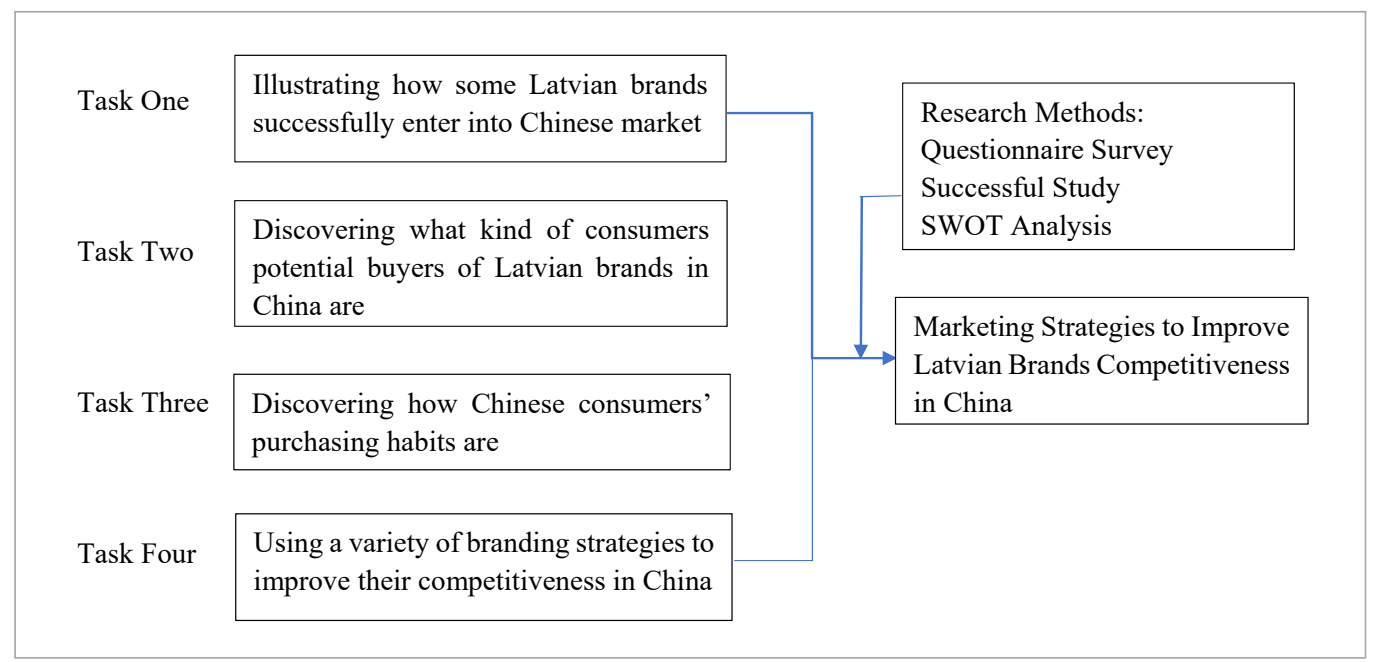

Figure 1

The Analysis of Latvian Brands Competitiveness in China Logical Diagram 
per at last illustrates some advisable marketing strategies to improve Latvian brands competitiveness in China.

Main tasks of this paper: (1) to illustrate how some Latvian brands successfully enter to Chinese market; (2) to discover what kind of consumers are potential buyers of Latvian brands in China and how their purchasing habits are; (3) to use a variety of branding strategies to improve their competitiveness in China.

The main finding of this research is that raising Latvian brands competitiveness needs to adapt to Chinese people's habits, and Chinese consumers will favor more Latvian products by building unique brands image and taking advantage of their "face" mentality.

Research methods in this research are SWOT analysis, questionnaire survey, descriptive and analytical method of analysis, secondary analysis and analysis of scientific literatures.

Latvian Brands Competitiveness Survey among Chinese Consumers

\author{
Figure 2 \\ Age Distribution \\ of Latvian Brands \\ Consumers in China
}

Nowadays China is one of the most important economies in the world. As the economy is developing in a quite rapid and smooth way, the income of people is rising, and that leads to growing middle class. Chinese consumers have more money to spend, so their shopping habits are changing fast. Looking back in China 's history, some significant economic, social and cultural changes have created a unique consumer market. In order to conquer China 's market, companies have to explore and understand the needs, requirements as well as behavior of Chinese consumers. In order to meet buyer 's wants, companies have to provide high quality products and services.

In order to finish this research, the author did a questionnaire survey in Beijing, Shanghai, Nanjing, Hangzhou, Guangzhou and Chengdu in 2016 summer. A sample of 5245 randomly selected consumers (876 from Beijing, 745 from Shanghai, 786 from Nanjing, 798 from Hangzhou, 1172 from Guangzhou, 868 from Chengdu), from these large-sized metropolitan areas received the questionnaires. Finally, 1265 consumers are Latvian brands users. ${ }^{1}$ Respondents received 5 RMB for completing the questionnaire. The respondents were asked to provide their perception of Latvian products and Latvians brands in selected grocery products such as snack, dairy products, cosmetics, alcohol, fish products etc. The questionnaire is anonymous. Nobody was recognized in the analyzed result. All data will be used for research objective only. This specific questionnaire for these Latvian products users consists of 8 questions. Also the $4^{\text {th }}$ question is about the survey of their age range (Younger than twenty, Twenties, Thirties, Forties, Older than forties). The survey result will be showed in the Figure 2 .

We can see in the survey result that the main groups are new generation, twenties, thirties, wealthy forties.

1. New generation

Source: Questionnaire of Latvian Products among Chinese Consumers 2016.
In China, the young age consumers (not older than the age of 18) are attracted by Euro-

1 These data was collected by the author from the Questionnaire of Latvian Products among Chinese Consumers 2016, and the six cities can mostly represent the north, south, west and east part of the whole China. 
pean products, as well as Latvian products. Most of young generation people are pursuing the fashion to get the unique characters and think all the possible ideas to purchase some European brands. Although most young buyers in this generation do not have good salary or enough savings, their parents' decisions are usually influenced by them on cosmetics, electronics, food and clothing significantly. Internet shopping is an effective way to lead this group of consumers to dig their purchasing potential abilities (April-June 2015, Social Media in China).

\section{Twenties}

Consumers in the generation under the one-child policy usually have different consumer behaviors with their parents. They usually do not save money and spend all of their income on some consumptions in advance, such as entertainment and travelling. They want to be unique and often choose shopping online searching for Latvian brands that help them dominate their personal characters, and they sometimes can also be very desperate to look for unique brands. As the consumers in twenties age will start to get married, their consumption style could become a little more conservative. Although they are interested in convenient products and high-quality brands, they still spend more on Latvian brands than older generations.

\section{Thirties}

Talking about Latvian brands consumers in thirties, they usually like spending more on clothing and some food, and go to buy their favorite food in shopping centers or internet. Nearly most of consumers in this group are experienced shoppers and skillful on selecting brands comparatively. They often pursue valuable and high quality Latvian products such as amber or amber jewelries rather than cheaper products. Usually these people around thirties will be the main consumers of Latvian products.

\section{Wealthy forties}

Consumers in this generation mostly share the same preferences as the frugal thirties, but their career is usually in the government institutions or large national enterprises and they have comparatively high salary. Even if they have to look after their parents and raise children, they still would like to pay extra money for high end Latvian brands. In the coming five or six years, consumers in this age range will have less childcare responsibilities and consumption. Meanwhile these consumers will definitely increase expense on healthcare, luxurious, natural, organic and high-quality Latvian products.

In 2016, the main indicator of fast-growing consumer product categories of Latvian brands are listed in Table 1. Skincare item producer STENDERS entered Chinese market in 2012 and company 's turnover in 2016 was already 46.12 million Euro (EUR). Two years before (2010) amber seller Amber with Soul started to distribute amber jewelry in such large cities as Beijing and Shanghai. Last year company 's turnover reached 58.33 million EUR. Latvian traditional alcohol brand Riga Black Balsam entered Chinas market in 2008 and sweets producer Laima did it in 2013. Both companies have smaller turnover respectively 0.43 and 0.32 million EUR. Gift seller Riga Collection started to do business in Beijing in 2013, and reached 0.26 million euro turnover in 2016.

Also from the statistics of the two years in Figure 3, we can see that from 2013 to 2016, the five brands growth rate (Turnover) is stably not less than $10 \%$.

\section{STENDERS}

In recent years, Chinese people is getting rich. They can not only accept some cosmetics just from faces, however they gradually put some attention on the cosmetics for bathing skin care. Although the consumption of personal care products is quite low, China has a big potential to expand this market. Mostly, Chinese men do not like some cosmetics, and some Chinese buy

The Most Competitive Latvian Brands in China 


\begin{tabular}{rl|c|c|l}
\multicolumn{1}{c|}{$\begin{array}{c}\text { Table 1 } \\
\text { Main Indicators } \\
\text { of Fast-growing } \\
\text { categories of } \\
\text { Latvian Brands in } \\
2016\end{array}$} & STENDERS & Turnover (2016, million EUR) & Entry Year & \multicolumn{1}{c}{ Market Distribution } \\
\cline { 2 - 5 } & Amber with Soul & 46.12 & 2012 & $\begin{array}{l}\text { All the first tire cities and Most second } \\
\text { tire cities, and some third tire cities }\end{array}$ \\
\cline { 2 - 5 } & $\begin{array}{l}\text { Riga Black } \\
\text { Balsam }\end{array}$ & 58.33 & 2010 & $\begin{array}{l}\text { Beijing, Guangzhou, Shanghai, } \\
\text { Chengdu, Shenzhen, Chongqing }\end{array}$ \\
\cline { 2 - 5 } & \begin{tabular}{l} 
Laima \\
\cline { 2 - 5 }
\end{tabular} & 0.43 & 2008 & $\begin{array}{l}\text { Beijing, Shanghai, Guangzhou, } \\
\text { Ranjing }\end{array}$ \\
\hline Riga Collection & 0.32 & 2013 & Shanghai, Beijing \\
\hline
\end{tabular}

Source: Ministry of Foreign Affairs of China, 2016.

Figure 3

Fast-growth Consumer Product Categories of Latvian Brands in 2016

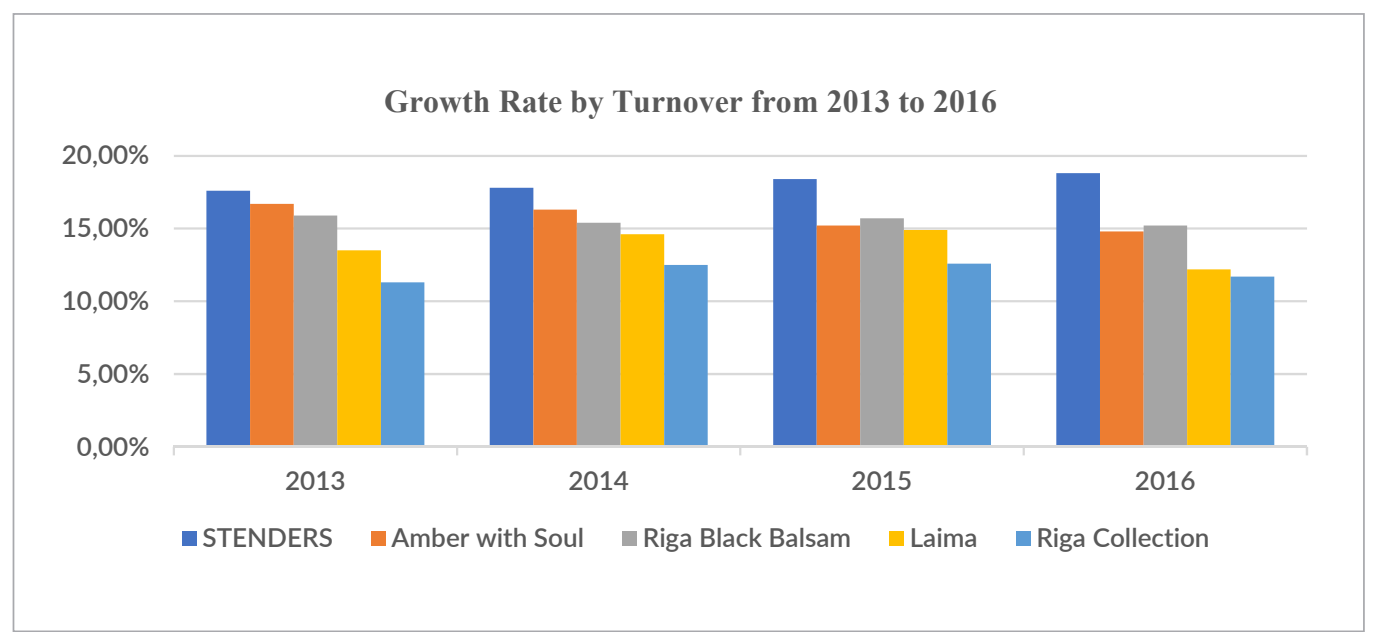

Source: Ministry of Foreign Affairs of China, 2016.

only shampoo and don 't spend money on conditioner. However, in past years peoples ' incomes are increasing, so more and more consumers are able to spend more money on non-essential hygiene and cosmetics products, especially body and bath cosmetics and natural organic personal care products.

STENDERS is positioning itself as a brand that is inspired by the nature of the North. It pays a special attention to showering, bathing and body skin care rituals. The products are designated to amplify the positive feelings that different fragranced skincare products can give to the customer. Special attention is given to the way how consumers are treated in STENDERS shops. Since other cosmetics (Such as LOCCITANE, LANCOME, Estee Lauder) doesn't have bath skin care products, the innovative design of hand-made essential oil soaps and sea salt bath bubble balls make the brand very unique and hard to be replaced. As other cosmetic brands represent in order to offer wide variety of options in the particular product segment, STENDERS can call itself the best gifts from Latvia.

STENDERS is also one of the largest cosmetics producers in Northern Europe. It consists of competent and creative people united by the idea of "gardening" feelings. Its natural feelings are implemented in more than 280 products and it has more than 435 stores in 46 countries, for example, in Latvia, Estonia, Norway, Switzerland, Sweden, Lithuania, Slovenia, Finland, Brazil, 
Saudi Arabia, Russia, Turkey, Kyrgyzstan, South Korea, Iran, Japan, Germany and China. In 2012 STENDERS successfully came into China market. Now more than 300 STENDERS chain shops open in more than 50 main cities of China.

\section{Amber with Soul}

In China, jewelries are still generally expensive for most people. Usually some rich Chinese people turn to natural ornaments or gemstone, such as amber, while low income people often wear gold or silver. In recent five years, many Chinese consumers think the private labels or signs they have tried are not worth the premium prices. At the same time, these consumers are concerned about some fake gemstones or the original jewelry stone, so they are willing to pay slightly more for amber jewelries.

Amber with Soul is the largest amber ware manufacturer in Latvia and also an outlet shop. The jewelries are envisioned by professional designers and made by experienced amber folk craftsmen. All the items available in the shop come straight from the factory. They have the largest selection of certified amber jewelries, souvenirs, and wares with gold and silver at the manufacturer's prices. At the same time one can see growing demand for amber and amber products (by $16.7 \%$ in 2016). According to the statistics the branch increases by about $14.5 \%$ annually. In 2012 the turnover reached over 1.65 billion CNY. Chinese amber fans also like putting amber stones in their home, clothes pockets, office desk or cabinet. They call the Baltic amber "Hupo". And they also like to choose this brand as gifts to their children or parents. According to the China association for jewelry survey in 2015 , there is a sustainable and relatively rapid growth on the amber jewelry market.

\section{Riga Black Balsam}

Riga Black Balsam is one of the alternatives for other than local alcoholic drinks in China in recent 5 years. As we know, in black balsam, the herbs are mixed with alcohol and water, and this mixture is kept in wood barrels for more than 45 days, which produces special herbal taste and unique scent. Traditionally, the recipe was created by Abraham Kunze, a pharmacist living in Latvia on 18th century. And the brand recipe is always kept secret. Meanwhile the quality of Riga Black Balsam is carefully controlled and checked in the lab for all the stages of production. It is an ecological alcohol, and the ingredients of it are tested as well. The company chooses the raw materials and ingredients and controls these materials very carefully to ensure the application of traditional technologies and introduce innovative improvements of such methods to guarantee the highest brand quality. In 2013, Riga Black Balsam was declared the best imported brand from Latvia. It is regard to the good logo, "Riga Black Balsam, better understanding northern Europe".

\section{Laima}

Love and romance are the greatest value of Laima chocolates and the main secret behind its amazing taste and aroma. When this atmosphere is presented, it always comes back to you, and that is exactly why Laima chocolate helps you to choose love at this very important time in life, which opens the door to happiness for all of us. In Riga, Zala Street 4, Theodor Riegert opened the first chocolate factory in Latvia. Over the years, Riegert's factory became one of the largest sweets manufacturers in the Baltic States and Russia. In 1938, there were five stores of "Laima" brand in Riga, while the total number of stores in other Latvian cities reaches 10. Sweets of "Laima" are exported to the USA, Great Britain, Africa, France, and Sweden.

In 2013, this famous Latvian brand successfully entered Shanghai market. "Laima" sweet shops in Shanghai is just like small factory of sweets where the time stops. When you take the first step inside the shop you are embraced by a romantic atmosphere and covered in chocolate scent that almost brings the same taste as in Latvia. Customers here can find the beloved sweets from 
"Laima", "Selga" and "Staburadze" as well, and the friendly sellers will tell you more about new sweets you haven't tried yet but should. There are small coffee shops in these chain shops in which you can take a rest and stop to smell the chocolate! When walking into the shop, consumers will enjoy their leisure moments with a cup of coffee and a piece of delicious cake.

5. Riga Collection

Riga Collection sells several kinds of products including carpets from natural materials (Nature 's Carpet). Riga Collection 's, as a natural carpet brand, line of carpets has been tailored to accommodate the consumer who is willing to make a flooring purchase decision with consideration to its environmental effect, but does not wish to sacrifice quality and style on production. Nature's Carpet strikes this balance successfully, offering over 45 colors and styles of $100 \%$ wool carpets.

In recent years, Chinese young people are beginning to celebrate Christmas for the sake of fashion. Before each New Year, some Chinese young people would like to buy some Christmas gifts for friends and family members as well. With three months left until Christmas in 2013, the first Latvian store "Riga Collection" in Sanlitun Street in Beijing alongside the brands "China Gold" and "Semmir" opened a pop-up Christmas store. Located in the "Wangfujing" mall, the store opened for two weeks in Christmas time, giving insight in the traditions of celebrating Christmas in Northern Europe country Latvia- the country that started the decorating of Christmas trees. The "Wangfujing" shopping mall is the prestigious comprehensive shopping center in Beijing with about 80,000 people visiting it daily. In the opening month, their turnover got 235,000 RMB. In the next two years, Riga Collection also came into Shanghai and Guangzhou successfully. The theme for the pre-Christmas sale in Riga Collection in last year was "Kids Design-Connecting to the future". Therefore, the Latvian stand features handmade local products, accessories and children paintings.

The others companies in Latvia are still looking for the opportunity to explore their marketing share in China. Some of these food companies have already built their factories in China to gain good reputation in Chinese market, but their marketing strategies are still not very effective due to the different consumer behavior psychology. 2016, the 1+16 forum was successfully held in Riga, which effectively consolidated the cooperation between China and central and eastern European countries. The total trade volume between Latvia and China exceeded 342 million euros; Latvia and China traded goods over 0.85 million euros per day. In the first half of the year 2016, Latvian investment in China amounted to 1.8 million euros and Chinese investment in Latvia was 1.5 million euros. $^{2}$

The Channels for Improving Latvian Brands Competitiveness in China

Chinese consumers are powering the growth of China and the global economy and their power will only grow in the next decade. No one could have predicted even seven years ago that major brands from Western multinational corporations, to small and medium-sized enterprises, would add 11-11 (Singles' Day), 6-18 (founding day of JD.com), October 1-7 (National Day Golden Week) and the Spring Festival (Chinese New Year Golden Week) to their holiday promotions calendar. Nor could anyone have predicted the impact that Chinese travelers would have on cities, brands and service providers around the globe.

We can see that China is the fastest-growing consumer market in the world. "China's Super Consumers" have now gone beyond mimicking the patterns of more established Western shoppers to being the trendsetters and innovators. There is a super-feedback loop taking place whereby consumer demands are shaping how e-commerce giants like Taobao, Alibaba, Jindong (JD) and Amazon are developing new models of retail and technology to serve them. Retailers from Latvia are catering to these shoppers and creating new demand and access to goods through innova-

2 The statistics is from Latvia - China Business Council in 2015. 
tion. The Latvian Cabinet of Ministers on November $1^{\text {st }}, 2016$ supported signing of a memorandum of understanding between the Latvian and Chinese governments to promote implementation of the Silk Road economic belt initiative and the 21st century Maritime Silk Road initiative. Now we can do the SWOT analysis for these successful Latvian brands in China in Table 2 below.

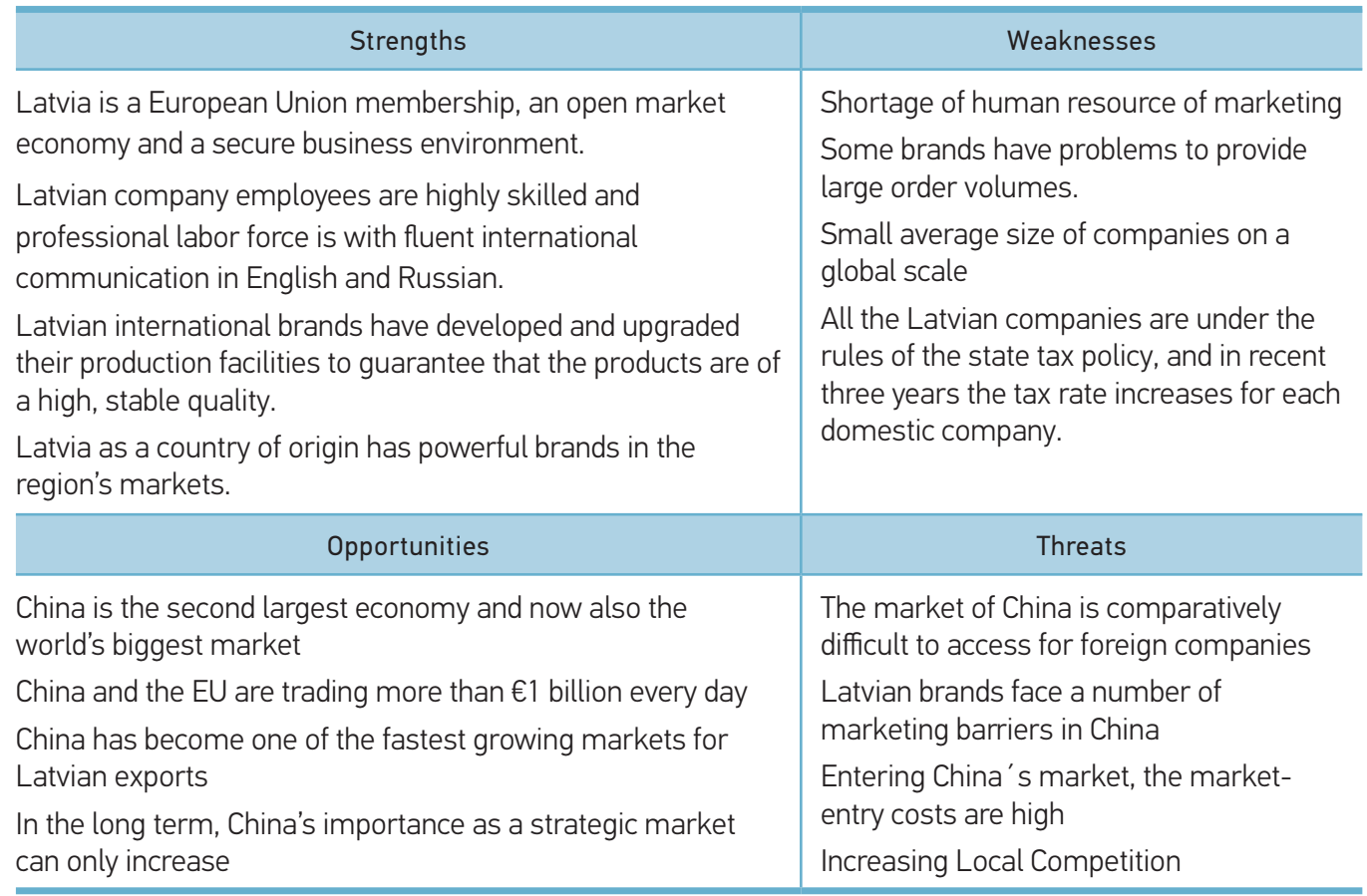

Source: Latvia-China Business Council, 2015.

For Latvian brands in China, one of the key market entry obstacles is low brand awareness in the local market. A Latvian brand could be well known in large cities in China, but it is still important for the retailers to position their products suitably within more and more small cities in China. Chinese customers pay much attention on brands that they have heard of, and those which are with good reputation within others consumers. Thus, building brand recognition is very important for some new Latvian brands in China. It will make a good impression about the brand among Chinese consumers. Innovative advertising materials are also essential to promote a brand and help it to stand out from other similar brands and capture consumers' imagination.

As China opened its market to Latvian investment, commodity availability was opening at the same time. The previous Latvian companies have already entered Chinese market before 2009, and they are cooperative venture with a local company in China. Today, China has lots of marketing types, from shopping malls and hypermarkets to online stores and night markets. Selecting the effective channels for selling their products can be essential to Latvian brands building.

1. Large scale shopping malls and selling stores

Wanguard Group has announced plans to operate 25-30 shopping centers in west of China by 2020. Latvian retailers should work more on these outlets at middle or large scale shopping malls. Some second tire cities, such as Nanjing, Wuhan, Tianjin, Xi'an, Chengdu, Hangzhou, will also accept direct selling stores over Latvian brands soon. This retailor format can be learned by some Latvian cosmetics retailers. In general, more large scale shopping malls will be possible to open in main cities of western China.
Table 2

SWOT Analysis of Latvian Brands in China 


\section{Local chain supermarkets}

In China, supermarkets are not always profitable, because these supermarkets fiercely have some competitive rivals from shopping malls and hypermarkets. First tire Chinese cities are full of international stores, but potential Latvian brands buyers in smaller cities are often not rich enough to purchase products in some international supermarkets.

Since rich Chinese buyers are increasing in middle and small size cities, at the same time the demand for better quality of living have emerged. They are gradually choosing the products which are related to a high quality of life and a higher social status. So the local chain supermarkets are expanding rapidly in larger cities, which offer more high end and foreign products.

\section{Hypermarkets}

Some Chinese consumers like spending time for shopping with their friends or families in leisure time. Hypermarkets with a shopping gallery and specialty stores or some popular restaurants are very welcomed in large cities. Although Chinese incomes are increasing significantly, consumers will still prefer to buy their necessities in hypermarkets due to the one-stop shopping experience and the low prices. So the hypermarkets will continue to be successful in main cities of China. As Chinese urbanization is running faster, hypermarkets are looking for some new opportunities to invite some exotic foreign brands to join their shopping circles.

4. Neighborhood shops

Typically, neighborhood shops include Wanguard Group's branch companies and Shentong Express. Actually, some inefficient supply chains and small scales of operation are still existing. As incomes are getting higher, some Chinese consumers prefer neighborhood shops more than the ones from shopping malls based on convenience.

5. Online stores

Young citizens not older than 35 years old in China are willing to pay a fee for the delivery to their living places as they are too busy to shop in grocery shops. Latvian branding retailers have to look for some new opportunities to make some changes to improve the marketing range of their online merchandise. Indeed, they need to think about shorter delivery times to meet consumer needs, and advance their supply chain. Alongside of establishing their good business image in the next few years, still many Latvian brands are trying to enlarge their marketing share in Chinese market. It is also necessary for Latvian enterprises to focus on presenting the specific qualities and uniqueness of their brands compared with other competitors and the advantages of their products. Because of some fake product scandals in China in the past few years, consumers in China actively research information about products and companies, so people are more informed and sophisticated than European people. They use social media and search energy to find information about a brand or product, so that they can make the best final purchasing decision. Sometimes the decision about buying or not-buying some items is based on comments of other people who have bought the items. It 's because other peoples ' experience sometimes seems to be more trustworthy than the information provided by the seller itself.

Since China has a large population and very competitive markets for the suppliers, the consumers are gradually getting more price sensitive. When the buyers make purchase decisions, the price is a key factor for the buyers. However, because of the specific culture, Chinese pay much attention on social status and faces. They are brand conscious. Thus, if brands can bring them a higher social status, they usually like to pay high extra premium for them. Chinese buyers are also mistrustful more or less. For example, they don 't trust on-line shops that want to receive payment before sending the product to the customer. Because of this issue with trust between 
both parties, on-line shops started to use third-part payment systems, for example, Alipay. Buyers transfer payment for the product to Alipay, and after the person receives the product, thirdpart payment system transfers money to the seller.

The competitiveness of Latvian brands in China can be assessed to the companies' competitiveness. A number of characteristic aspects of Latvian firms should be taken into account of choosing a competitiveness model for assessing of Latvian firms' competitiveness in China. Firstly, Latvia has a great number of small and medium sized enterprises (SME). The proportion of the SME in total number of Latvian enterprises was $96.5 \%$ in $2015^{3}$. Secondly, Latvian companies have insufficient experience in the operation in foreign markets and relatively short experience in the internationalization of business compared with those large companies from Western Europe. Latvia is an independent country since 1991 and Latvian firms operate in the free market conditions and accumulate experience operating in foreign markets since 1990s. It indicates that the competitiveness of Latvian companies can be useful for assessment of competitiveness of Latvian brands in China market. In fact, most of customers in China like to browse the comments of other people about some products that they are interested in. Latvian companies must understand certain factors to successfully build their brands reputation in Chinese consumers. In the end, marketing strategies to Improve Latvian companies competitiveness in China can be concluded as below:

\section{Most Chinese consumers favor European brands}

Product safety scandal and low quality brand image have scared Chinese consumers away from lots of domestic products. People are often willing to pay extra money for brands form Italy, Germany or France just to ensure the quality of important items, for example, baby formula. Some Chinese companies have noticed this trend, so they register their headquarters in European countries like Germany or France and brand products as "Originally Imported". By doing that these companies try to make the products more appealing to Chinese consumers. However, it 's becoming more and more difficult for buyers to distinguish foreign from local brands. Latvian companies should take advantage of this phenomenon to develop their resource to ensure Chinese consumers know their products are original from Europe.

\section{Brands image plays an important role in China}

Chinese like to give a comment on some brands in social media. This includes, for example, sharing the quality of products, price point, advantages and disadvantages etc. These comments strongly influence the reputation of a brand, and help customers to make (or not make) a purchasing decision. For example, China Daily in March 2015 revealed that clenbuterol, a kind of additive that accelerates growth, was inspected in beef sausage from the Yurun Group, a famous meet manufacturer. In the next few months, Yurun's retail sales dropped 37 percent, and many consumers are already scared to buy its products.

\section{Bargaining and discount seasons are common in China}

Chinese is a frugal nationality, especially those people were born before the liberation of China in 1949. Most of old Chinese consumers above 60 years old would like to save as much as they can. Retailers in shopping centers, supermarkets, or direct selling stores often decrease the prices of high end products and high demand-price elastic items, such as cosmetics, alcohol, personal products, and clothes. These retailers limit the quantity of products with discount, so this strategy may lead consumers buy these products more in one time. These promotion ways were quite effective and successful as long as frugal Chinese consumers are willing to spend less money but to get more benefit.

3 The statistics is from Central Statistical Bureau of Latvia in 2015. 


\section{4. "Face" matters}

For Chinese it 's very important to have and keep a good "face". By "face" people usually mean good traits such as pride, honor and dignity. In order to keep a "face" some people will choose more expensive products. It also can prove that they have high social status. For example, when purchasing gifts during Chinese New Year for family members, company leaders, or important friends, some Chinese consumers usually will choose gifts that have the appropriate value and pay much attention to the package of products for the receivers. Consumers that cannot afford an expensive gift probably will choose the product with the beautiful packaging within their purchasing power. Finally, some buyers will even pay more money for the packages, though the product value is of equal quality or cheaper than the package.

\section{Adapt to Chinese people's habits}

Providing a typical example of adapting Chinese consumer habits, Black Balsam has already occupied alcohol market in north of China, but Chinese white alcohol drinking habit has been existing for a long time in history. More and more Chinese people gradually prefer Black Balsam because it is healthier than white alcohol, and advertised as herbal alcohol. On the other hand, some Latvian brands retailors had better change their products to get closer to Chinese style more. A good example is KFC, which tried to promote their spicy fried chicken when it entered into China market in 1995, because Chinese people like spicy food somehow. When they get to know that pork and fish are more popular in China, KFC adapted to Chinese people's eating habits and launched several kinds of fish burgers.

\section{References}

Alon, I., Littrell, R. F., \& Chan, A. K. (2009). Branding in China: Global product strategy alternatives. Multinational Business Review, 17(4), 123-142. https://doi.org/10.1108/1525383X200900030

Li, G., Li, G., \& Kambele, Z. (2012). Luxury fashion brand consumers in China: Perceived value, fashion lifestyle, and willingness to pay. Journal of Business Research, 65(10), 1516-1522. https://doi. org/10.1016/j.jbusres.2011.10.019

Zhou, L., \& Wang, T. (2014). Social media: A new vehicle for city marketing in China. Cities, 37, 27-32. https://doi.org/10.1016/j.cities.2013.11.006

Gertner, D. (2011). Unfolding and configuring two decades of research and publications on place marketing and place branding. Place Branding and Public Diplomacy, 7(2), 91-106. https://doi.org/10.1057/ pb.2011.7

Zhang, S. S., van Doorn, J., \& Leeflang, P. S. (2014). Does the importance of value, brand and relationship equity for customer loyalty differ between Eastern and Western cultures?. International Business Review, 23(1), 284-292. https://doi.org/10.1016/j. ibusrev.2013.05.002

Chu, S. C., \& Sung, Y. (2011). Brand personality dimensions in China.Journal of Marketing Communications, 17(3), 163-181. https://doi. org/10.1080/13527260903387931

Bulis, A., \& Skapars, R. (2012). Competitiveness of Latvian companies in People's Republic of China. HUMANITIES AND SOCIAL SCIENCES LATVIA, 23.
Kozlinskis, V., \& Losane, L. (2011). LATVIAN EXPORT OF GOODS: PROBLEMS AND SOLUTIONS. Journal of Business Management, (4).

Dickson, M. A., Lennon, S. J., Montalto, C. P., Shen, D., \& Zhang, L. (2004). Chinese consumer market segments for foreign apparel products. Journal of Consumer Marketing, 21(5), 301-317. https://doi. org/10.1108/07363760410549131

De Mooij, M., \& Hofstede, G. (2011). Cross-cultural consumer behavior: A review of research findings. Journal of International Consumer Marketing,23(3-4), 181-192.

Pancenko, E., \& Ivanova, T. (2016). THE COMPETITIVE ABILITY OF LATVIAN EXPORT: CURRENT SITUATION AND PROSPECTS. Journal of BusinesS Management, (11).

Pancenko, E., \& Ivanova, T. (2016). THE COMPETITIVE ABILITY OF LATVIAN EXPORT: CURRENT SITUATION AND PROSPECTS. Journal of BusinesS Management, (11).

Ille, F. R., \& Chailan, C. (2011). Improving global competitiveness with branding strategy: Cases of Chinese and emerging countries' firms. Journal of Technology Management in China, 6(1), 84-96. https://doi.org/10.1108/17468771111105677

Chinese Business Review. (2011). Understanding Chinese Customers.Retrieved July 1, 2011, from https://www.chinabusinessreview.com/understanding-chinese-consumers/ 


\section{FENG HAIDONG}

\section{Doctoral student}

Faculty of Business, Management and Economics, University of Latvia

Fields of research interests

Economics, Marketing, Financial Management, Financial Engineer

\section{Address}

Aspazijas blvd 5, Riga, Latvia

Tel. +37125336787

\section{PRIEDE JANIS}

Dr. oec. Associate Professor, Head of the Department of Economics

University of Latvia, Faculty of Business,

Management and Economics

Fields of research interests

Microeconomics, Macroeconomics, International Business Economics, Export Marketing, Production and Operations Management

Address

5 Aspazijas blvd., Riga, Latvia
About the authors 